\title{
Valorization of the Energy Potential of Liquid Wastes Effluents: Case of an Oil Palm Agro-Industry in a Tropical Humid Zone
}

\author{
Kra Essi Kouadio Francis ${ }^{1}$, N'Guessan Kotchi Remi ${ }^{2,}$, , Adama Ouattara ${ }^{3}$ \\ ${ }^{1}$ Laboratory of Motors and Energy Conversion Machines, National Polytechnic Institute Houphouët Boigny (INP-HB), Yamoussoukro, Côte \\ d'Ivoire \\ ${ }^{2}$ Laboratory of New and Renewable Energy Technologies, National Polytechnic Institute Houphouët Boigny (INP-HB), Yamoussoukro, Côte \\ d'Ivoire \\ ${ }^{3}$ Laboratory of Industrial Processes, Syntheses and Renewable Energies, National Polytechnic Institute Houphouët Boigny (INP-HB), \\ Yamoussoukro, Côte d'Ivoire
}

\section{Email address:}

kraessi@gmail.com (K. E. K. Francis), nguessankotchi1@gmail.com (N. K. Rémi), adam_inphb@.yahoo.fr (A. Ouattara)

${ }^{*}$ Corresponding author

\section{To cite this article:}

Kra Essi Kouadio Francis, N'Guessan Kotchi Remi, Adama Ouattara. Valorization of the Energy Potential of Liquid Wastes Effluents: Case of an Oil Palm Agro-Industry in a Tropical Humid Zone. International Journal of Energy and Environmental Science.

Vol. 4, No. 1, 2019, pp. 10-17. doi: 10.11648/j.ijees.20190401.12

Received: January 29, 2019; Accepted: March 13, 2019; Published: April 10, 2019

\begin{abstract}
The latest analysis realized by the Anti-Pollution Center (CIAPOL) of Côte d'Ivoire in March 2017, reveals that the liquid effluents resulting from the processing of palm oil fruits in the industrial process of palm oil that is studied in this work are, highly charge in organic matter (COD are between $60000 \mathrm{mg} / 1$ to $90000 \mathrm{mg} / 1$; and there $\mathrm{BOD}_{5}$ are situated between $15000 \mathrm{mg} / 1$ to $30000 \mathrm{mg} / 1$ for a volume of $0.7 \mathrm{~m}^{3} / \mathrm{T}$ ). This is not in accordance with ISO environmental protection requirement and the decree $\mathrm{N}^{\circ} 01164$ - MINEF- CIAPOL- SDIID of 04/11/2008 which recommend a decrease of their $\mathrm{BOD}_{5}$ from $30000 \mathrm{mg} / 1$ to $3000 \mathrm{mg} / 1$ by treating liquid effluents in an effective anaerobic device with an recuperation and valorization (combustion in an biogas engine witch produce electricity) of methane that these liquid effluents contain. Doing so, this methane will not be rejected in the atmosphere. In the second hand by a final treatment of degraded effluents through the irrigation system of industrial plantations. It should be noted that for the case studied here, the average tonnage of production of Palm Oil fruit bunches is 200000 tons per year. This transformation of palm oil fruits will produce about $140000 \mathrm{~m}^{3}$ of liquid wastes per year. Base on laboratory experiences, the conclusion is that, $1 \mathrm{~m}^{3}$ of waste can produce $32 \mathrm{Nm}^{3}$ of biogas. Knowing that $1 \mathrm{Nm}^{3}$ of biogas equal $5000 \mathrm{kcal}$ which equal $5.81 \mathrm{kWh}$, in consequence a $17 \mathrm{GWh}$ producible of electricity per year is expected. The generated electricity can supplement all external energy power supplies to the plants and provide needed energy to all villages around. The project will allow the industrial process to reduce their energy cost as well as protecting the environment around. The work done here will be beneficial for the industrial process because it will allow on one hand to save energy and on the other hand to produce fertilizer for palm oil fields.
\end{abstract}

Keywords: Palm Oil, Waste Effluents, Sustainable Development, Energy, Biogas, Electricity, Environmental Protection

\section{Introduction}

There is more need for companies to support environmental initiative that reduce Greenhouse Gas Emissions. In the same aspect, the industrial process can gain market share by mastering processes and enhancing the use of all by-products stemming from their processing facilities [1]. In this perspective of sustainable development, Palm oil mill effluent is a good source of methane gas generation via anaerobic digestion [13]. According to Yacob, S. et al. [14], the biogas obtained from Palm oil mill effluent anaerobic digestion is mostly compose of bio methane $\left(\mathrm{CH}_{4}\right)$ and 
carbon dioxide $\left(\mathrm{CO}_{2}\right)$. For these reason, this study aim to determine the energetically valorization potential of Palm oil mill effluent in a palm oil industry of Côte d'Ivoire $\left(08^{\circ} \mathrm{N}\right.$; $05^{\circ} \mathrm{O}$ ). In this palm oil industry, for each ton of extracted oil, industry must treat one ton of waste made up of solid organic waste, raids, fibers, hulls and approximately 2.5 tons of liquids effluents. The raids are used as manure in the plantations; the fibers and the hulls are used as fuel in the boiler and the liquid wastes effluents are poured in the rivers. The rejection of these liquid effluents in the river without any treatment is the major problems for the environment and also for public health, because this waste is rich in $\mathrm{CO}_{2}, \mathrm{CH}_{4}$ which are greenhouse gases [2]. The greenhouse gases are gas compounds which absorb the infra-red radiation emitted by terrestrial surface and then, take part in climate warming. Moreover, problems related to the electricity consumption are great in this factory. Energy expenditure is very important in the production costs of the industrial company. With a view to continuous the improvement of its environment, to take an active part in sustainable development and to optimize the cost its electricity consumption, an internal reflection on the liquid waste processing was made with an aim of developing the liquid effluents in energetic form. In the literature, several authors have studies the valorization of palm oil waste effluents. Parveen et al [10], have proposed various treatment techniques of Palm Oil Mill Effluent (POME). This study shows that using vermicomposting technique is a good alternative sustainable management practice of this waste. Here, the objective is to determine the energetic valorization parameters of a Palm Oil waste effluent product by an industry located in Côte d'Ivoire.

\section{Methodology and Materials}

\subsection{Methodology}

Some parameters such as flow, $\mathrm{pH}$, temperature, were measured from January to August 2017. The samples were taken at the exit of the decenter, on September 10th and 15th 2017 from $7 \mathrm{am}$ to $5 \mathrm{pm}$. After the samples taken, they were sent to the laboratory for analysis. In addition, temperature and $\mathrm{pH}$ measurements were made in situ and the samples were conditioned and transported to the laboratory for further analysis (COD, $\left.\mathrm{BOD}_{5}, \mathrm{VMS} \ldots\right)$.

Another functional solution was to combine liquid effluents, livestock effluents and seed that as a low methanogen potential but a buffer capacity and providing bacteria. The simple liquid effluents studied above have been reused here. Wastes have been added to these simple liquid effluents. After that, the measure of physical and chemical parameters of this mixture have been made again.

\subsection{Materials}

The different materials used in all the process of analyses are given in table 1 with their characteristics.

Table 1. Materials and there characteristics.

\begin{tabular}{|c|c|c|}
\hline $\mathbf{N}^{\circ}$ & Materials & Characteristics \\
\hline 1 & $\begin{array}{l}\mathrm{pH} \text { meter } \\
\text { (Hanna) }\end{array}$ & $\begin{array}{l}\text { Measures the } \mathrm{pH} \text { values in a range of }-2 \text { to } 16 \text { with an accuracy of } 0.01 \text {. It consists in measuring the probe with the } \\
\text { resolution of } 0.1^{\circ} \mathrm{C} \text {. }\end{array}$ \\
\hline 2 & $\begin{array}{l}\text { Air furnace } \\
\text { (Memmert) }\end{array}$ & $\begin{array}{l}\text { It provides the temperature between } 5^{\circ} \mathrm{C} \text { to } 300^{\circ} \mathrm{C} \text { where the adjustable scale in increasing and decreasing the } \\
\text { temperature is } 1 \text {. For analyzes of the biogas technology system, it used mainly for the analysis of total solids with a } \\
\text { range temperature of } 103^{\circ} \mathrm{C} \text { to } 105^{\circ} \mathrm{C} \text {. It is also used to cook standard substance KHP for the preparation of } \\
\text { standard solution KHP. This solution is used to test the COD test kit. }\end{array}$ \\
\hline 3 & $\begin{array}{l}\text { COD cell test: } \\
\left.\text { (WTW }^{\mathrm{TM}} 250303\right)\end{array}$ & $\begin{array}{l}\text { COD Thermo-Reactor Test Kit: This thermo-reactor consists of } 12 \text { thermo-block holes that can hold a total of } 12 \\
\text { test tubes of size } 16 \mathrm{~mm} \text {. It can provide a program of } 8 \text { heating times by heating: } 148^{\circ} \mathrm{C} \text { in } 2 \text { hours; } 148^{\circ} \mathrm{C} \text { in } 20 \\
\text { min; } 120^{\circ} \mathrm{C} \text { in } 30 \mathrm{~min} ; 120^{\circ} \mathrm{C} \text { in } 60 \mathrm{~min} ; 150^{\circ} \mathrm{C} \text { in } 120 \mathrm{~min} ; 120^{\circ} \mathrm{C} \text { in } 120 \mathrm{~min} ; 100^{\circ} \mathrm{C} \text { in } 60 \mathrm{~min} \text {; and } 100^{\circ} \mathrm{Cen} 30 \\
\text { min. For the analysis of the biogas technology system, the program used is that of } 148^{\circ} \mathrm{C} \text { in } 2 \text { hours of digestion. } \\
\text { Photometer: In addition to use for COD testing, the } 6 \text {-wavelength filter photometer }(340 \mathrm{~nm}, 445 \mathrm{~nm}, 525 \mathrm{~nm}, 550 \\
\mathrm{nm}, 605 \mathrm{~nm} \text {, and } 690 \mathrm{~nm} \text { ) is also used for all common routine determinations. Cellular (round) tests for waste } \\
\text { water analysis } \\
\text { A COD cell test box has a total of } 25 \text { cells. For the analysis of the biogas technology system, } 2 \text { ranges of COD cell } \\
\text { test concentration are used, } 500-10000 \mathrm{mg} / 1 \text { and } 5000-90000 \mathrm{mg} / 1 \text {. The effluent sample is first oxidized with a } \\
\text { hot sulfuric solution of potassium dichromate, with silver sulfate as a catalyst. Second, the chloride is masked with } \\
\text { mercury sulfate. The concentration of green Cr3 + ions is then determined photographically, this may determine } \\
\text { that COD existed in the liquid effluents in the range of } 5000-90000 \mathrm{mg} / 1 \text {. }\end{array}$ \\
\hline 4 & $\begin{array}{l}\text { Muffle furnace } \\
\text { (M110 + thermosiphon) }\end{array}$ & $\begin{array}{l}\text { With the temperature controlled at } 550^{\circ} \mathrm{C} \text {, it is mainly used for the analysis of volatile solids and volatile matter in } \\
\text { suspension. }\end{array}$ \\
\hline 5 & $\begin{array}{l}\text { Laboratory water bath } \\
\text { (Memmert) }\end{array}$ & $\begin{array}{l}\text { This } 14 \mathrm{~L} \text { laboratory water bath regulates the temperature from } 5^{\circ} \mathrm{C} \text { to temperature up to } 95^{\circ} \mathrm{C} \text {. It is mainly used } \\
\text { for the evaporation of water in the effluent sample, using water vapor in TS analyzes. It is also used to evaporate } \\
\text { hexane which is used as a solvent in the analysis of oil and grease. }\end{array}$ \\
\hline 6 & $\begin{array}{l}\text { Desiccator } \\
\text { (Laborantin } 250 \mathrm{~mm})\end{array}$ & $\begin{array}{l}\text { It is used to place samples when analyzing ST and SV. Silica gel as the moisture absorbent and the indicator is } \\
\text { placed in the desiccator with the sample to reduce the moisture. }\end{array}$ \\
\hline 7 & $\begin{array}{l}\text { Analytical balance } \\
\text { (Selleton High Performance } \\
\text { Analytical Balance) }\end{array}$ & $\begin{array}{l}\text { The readability scale of this analytical balance is } 0.1 \mathrm{mg} \text { with a weighting range of } 210 * 0.0001 \mathrm{~g} \text {. It is mainly } \\
\text { used for ST, SV, SM and VMS analysis as well as the weighting of chemicals used in analyzes for volatile fatty } \\
\text { substances, alkalinity and for COD analysis. }\end{array}$ \\
\hline
\end{tabular}




\section{Results and Discussion}

\subsection{Daily Industrial Technical Parameters}

Table 2 shows the different technical parameters of the agro-industrial unit. In this table, sample 1 has been made the July $15^{\text {th }} 2017$ and the sample 2 the July $19^{\text {th }} 2017$. It must be notice that a production of $745.8\left(\mathrm{~m}^{3} /\right.$ Day) and 639.6 $\left(\mathrm{m}^{3} /\right.$ Day) of liquid effluents have been recorded during these two days of sampling.

Table 2. Daily production technical parameters.

\begin{tabular}{lll}
\hline & $\mathbf{1}^{\text {st }}$ sample & $\mathbf{2}^{\text {nd }}$ sample \\
\hline Date & $15-$ july & $19-$ july \\
Palm oil fruit bunch processed $(\mathrm{T})$ & 1130 & 820 \\
Industrial process capacity $(\mathrm{T} / \mathrm{h})$ & 90 & 90 \\
Effluents flows & $0,66\left(\mathrm{~m}^{3} / \mathrm{T}\right)$ & $0,78\left(\mathrm{~m}^{3} / \mathrm{T}\right)$ \\
\hline
\end{tabular}

\subsection{Monthly Industrial Technical Parameters}

In the figure 1, the flows average of liquid effluents measured since January 2017 to August 2017 have been recorded in order to know the real medium flow. This curve is very important because it shows different production of liquid effluents that can be used to product methane. This curve is like a guide in the prediction of methane production and subsequently electricity by the industrial process itself. In addition, figure 1 shows that the volume of liquid effluents is high during the first four months of the year. This situation is due to the high production of palm oil by the plant during this period. It must be notice that this period corresponds to the one of major palm harvest. Afterwards effluents flows decreases gradually from May to June with the decline in production of palm trees. There is an increase from July because of the small period of high production. Taking into account periods of high production, average production and low production, an average liquid effluents flow rate of 0.70 $\mathrm{m}^{3} / \mathrm{T}$ (ton of palm oil fruits processed) is determined. For the rest of the present work, this value will be used as the average liquid effluent flow rate.

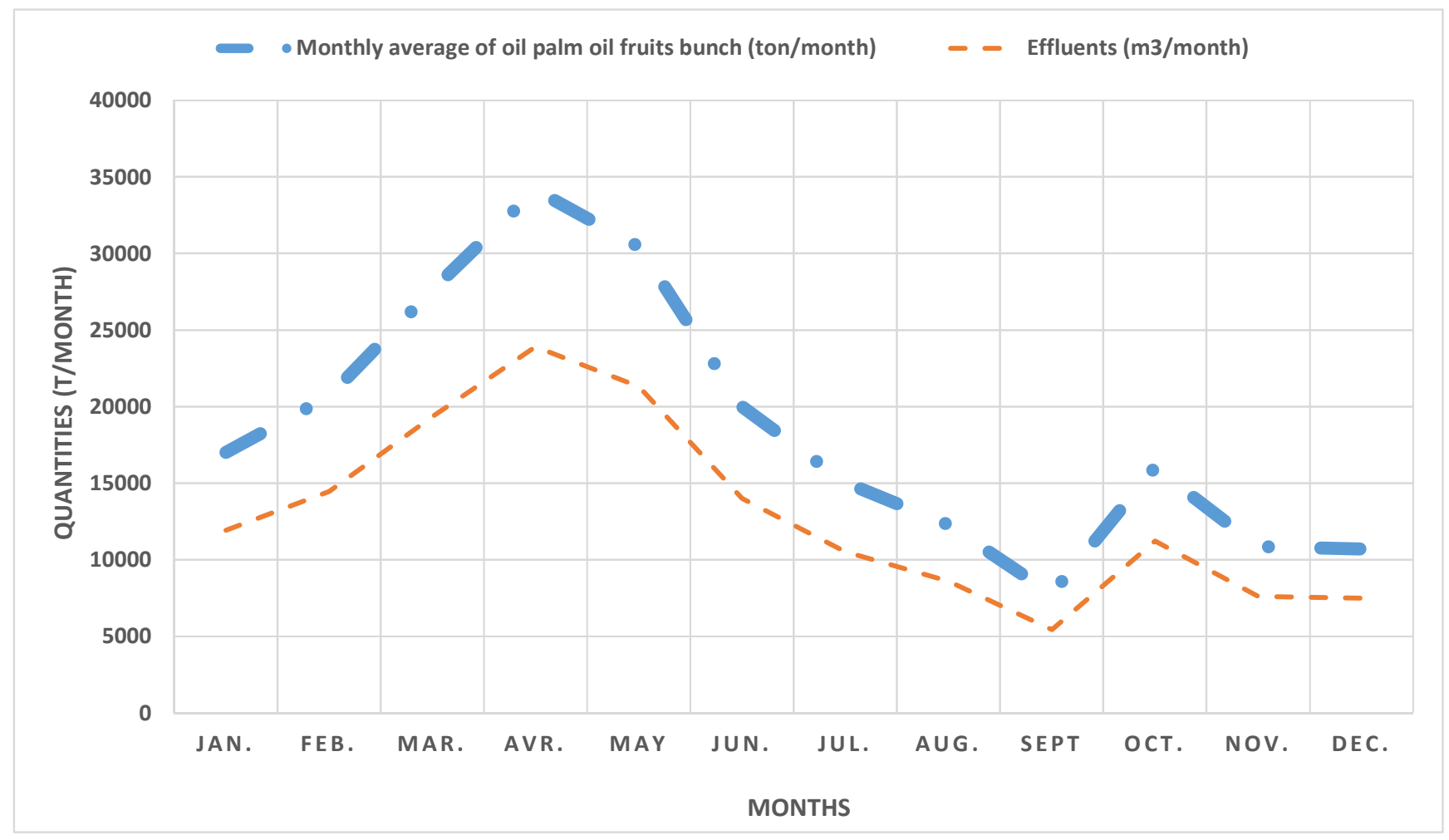

Figure 1. Comparison between liquid effluents curve and that of palm oil fruits bunch treated according to tonnage.

The plant processes on average of $250000 \mathrm{~T} /$ year of palm oil fruits bunches, that generates nearly $175000 \mathrm{~m}^{3}$ of liquid effluents per year. Based on the tonnages of palm oil fruits bunches processed over the last five years, one can calculate for each month, the actual amount of palm oil fruits bunches processed and the amount of liquid effluents discharged in the environment (figure 1).

\subsection{Analysis of Raw Simple Liquid Effluents Samples}

As mentioned above, two simple liquid effluents called sample 1 and sample 2 have been made on September 10th and 15th 2017 from $7 \mathrm{am}$ to $5 \mathrm{pm}$. The figure 2 below shows 
the results of the physicochemical characterization of these two samples.

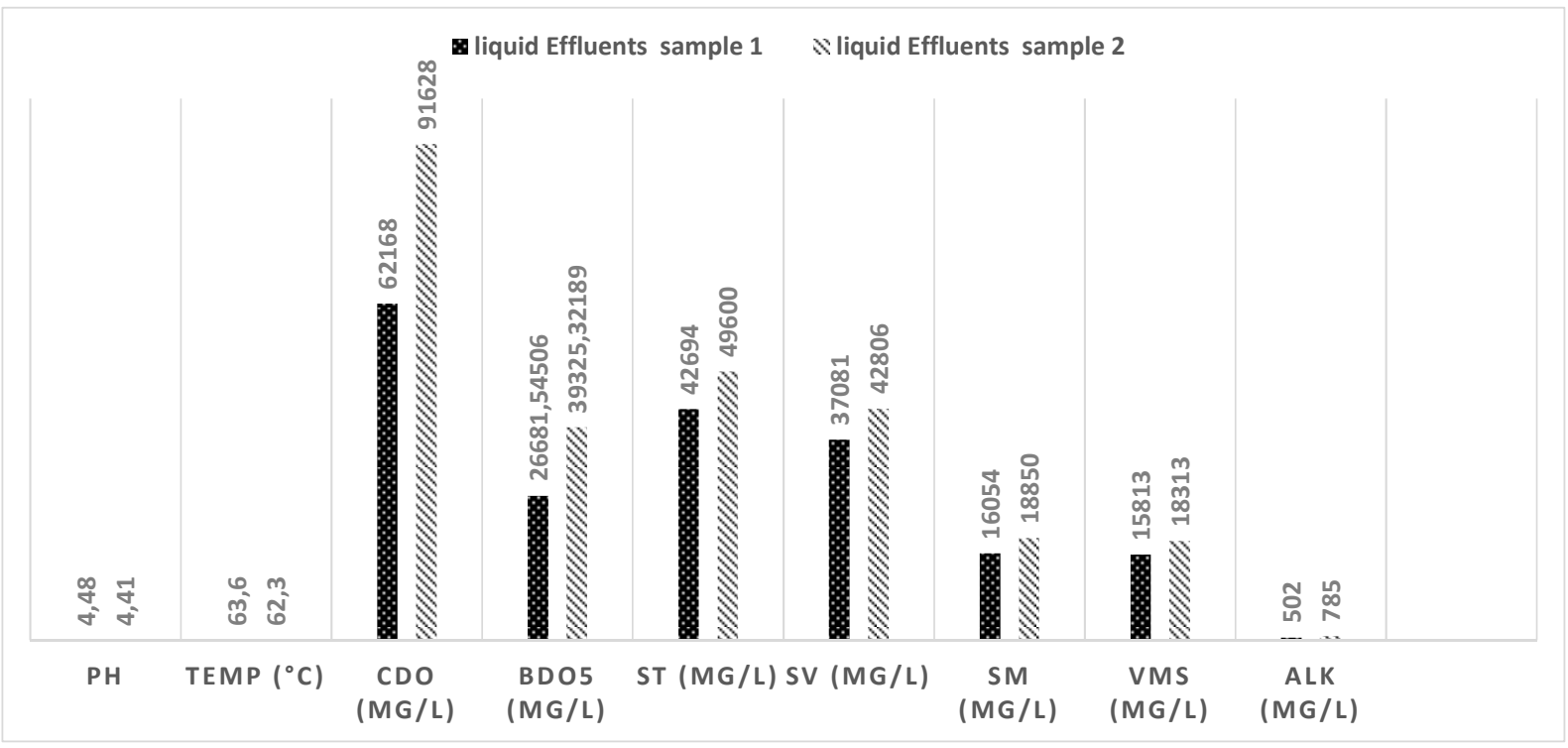

Figure 2. Physicochemical characteristics of two simple liquids effluents samples.

While analyzing figure 2, it appears that the liquid effluents collected at the decanter are acidic with high temperatures around $62^{\circ} \mathrm{C}$. In addition, there is a high concentration of VMS and a low alkalinity of these samples. The total solids concentration is relatively high. These solids can be easily degraded and converted into biogas [12]. These physicochemical parameters (figure 2) shows that the effluent conditions at the exit of the decanter are not favorable to influence the speed and efficiency of an anaerobic digestion of the liquid effluents [3-4].

\subsection{Analysis of Improved Samples}

Table 3 present le results of improved samples by adding wastes composed of (slurry of cattle).

1. Sample 1: $0.70 \mathrm{~m}^{3}$ of effluent $+30 \mathrm{~kg}$ of waste (seed mixed with slurry of cattle);

2. Sample 2: equal amount of liquid effluent and waste (seed mixed with slurry of cattle);

Table 3. Physicochemical characteristics of the liquid effluents mixed with wastes (samples 1 and 2).

\begin{tabular}{llll}
\hline \multirow{2}{*}{ Characteristics } & \multicolumn{2}{l}{ Effluents + Waste (seed mixed with slurry of cattle) } & Delta \\
\cline { 2 - 4 } & Sample 1+ waste & Sample 2 + waste & $-0,3$ \\
$\mathrm{pH}$ & 7,2 & 6,9 & 1,35 \\
$\mathrm{Temp}\left({ }^{\circ} \mathrm{C}\right)$ & 55,3 & 56,65 & 31163 \\
$\mathrm{COD}(\mathrm{mg} / \mathrm{l})$ & 73065 & 104228 & 13374,678 \\
$\mathrm{BDO}(\mathrm{mg} / \mathrm{l})$ & 31358,369 & 44733,047 & 5088 \\
$\mathrm{ST}(\mathrm{mg} / \mathrm{l})$ & 47856 & 52944 & -1618 \\
$\mathrm{SV}(\mathrm{mg} / \mathrm{l})$ & 47206 & 45588 & 3442 \\
$\mathrm{SM}(\mathrm{mg} / \mathrm{l})$ & 21558 & 25000 & 3480 \\
$\mathrm{VMS}(\mathrm{mg} / \mathrm{l})$ & 20908 & 24388 & 242 \\
$\mathrm{Alk}(\mathrm{mg} / \mathrm{l})$ & 531 & 773 & \\
\hline
\end{tabular}

The mix of effluents with wastes present higher concentration compares to the simple effluents. They present again a neutral $\mathrm{pH}$ and much better temperature.

\subsection{Potential Energy of Liquid Effluents}

The energy potential of a quantity of liquid effluents represents the amount of biogas that can be extracted to this effluents. To do sow $1 \mathrm{~m}^{3}$ of the two mixtures study above formed and examined in the anaerobic mills and the daily production of biogas was followed until an invariable rate was obtained.

Sample 1 required a relatively longer degradation time and a slower biogas production than sample 2 . This could be due to the different bacterial qualities and amounts of wastes in the two mixtures. From experiences, it must be notice that the anaerobic digestion process (biogas degradation and production) is subdivided into three phases:

1. An initial phase during which degradation and a high rate of biogas production are observed;

2. An intermediate phase during which there is a gradual decrease in the degradation and production of biogas;

3. A final phase during which both activities tend to stabilize and stop.

In the case of sample 1 , a quantity of $32 \mathrm{~m}^{3}$ of biogas is generated from $1 \mathrm{~m}^{3}$ of solution (mixture of effluents with waste). On the other hand, in sample 2 , which contained 
more wastes, there was a short degradation time of the COD with a higher biogas production, of the order of $39 \mathrm{~m}^{3} / \mathrm{m}^{3}$ of

mixture (mixture 2). (Figures 3 and 4).

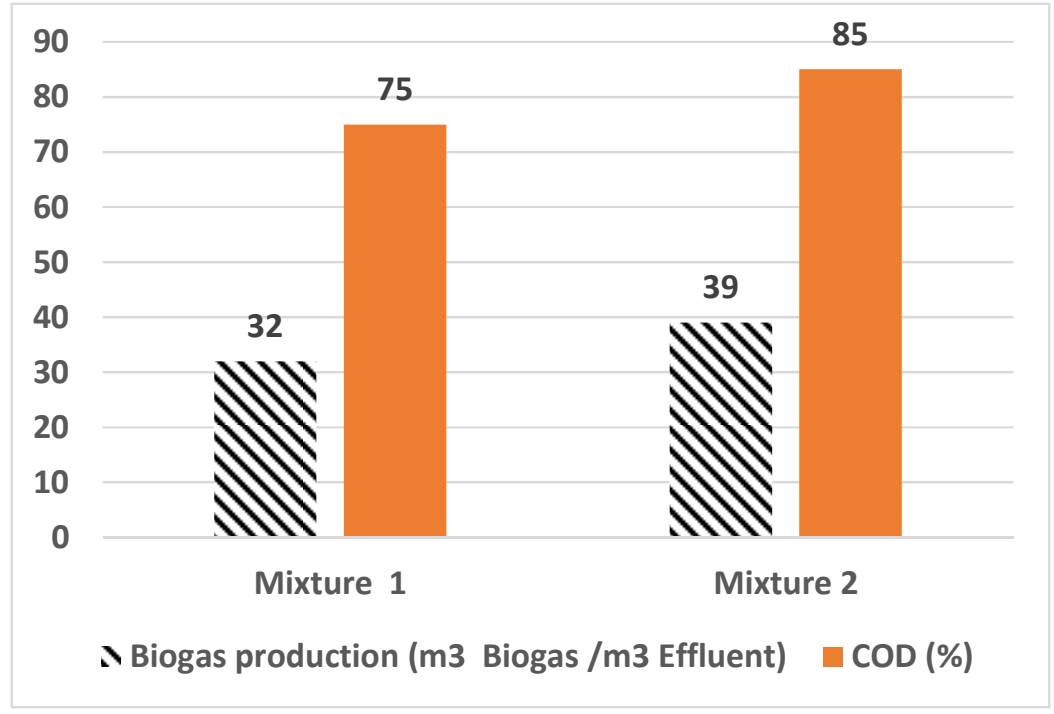

Figure 3. Biological degradation and biogas production with various proportions of mixture.

It appeared (figure 3) that under anaerobic conditions, the production of biogas ranged from $32 \mathrm{~m}^{3} / \mathrm{m}^{3}$ of mixture to 39 $\mathrm{m}^{3} / \mathrm{m}^{3}$ of mixture while nearly $75 \%$ of the degraded COD concentration is observed. It is also apparent from the experiment that the production of biogas was made during a residence time of the bacteria of 5 days.

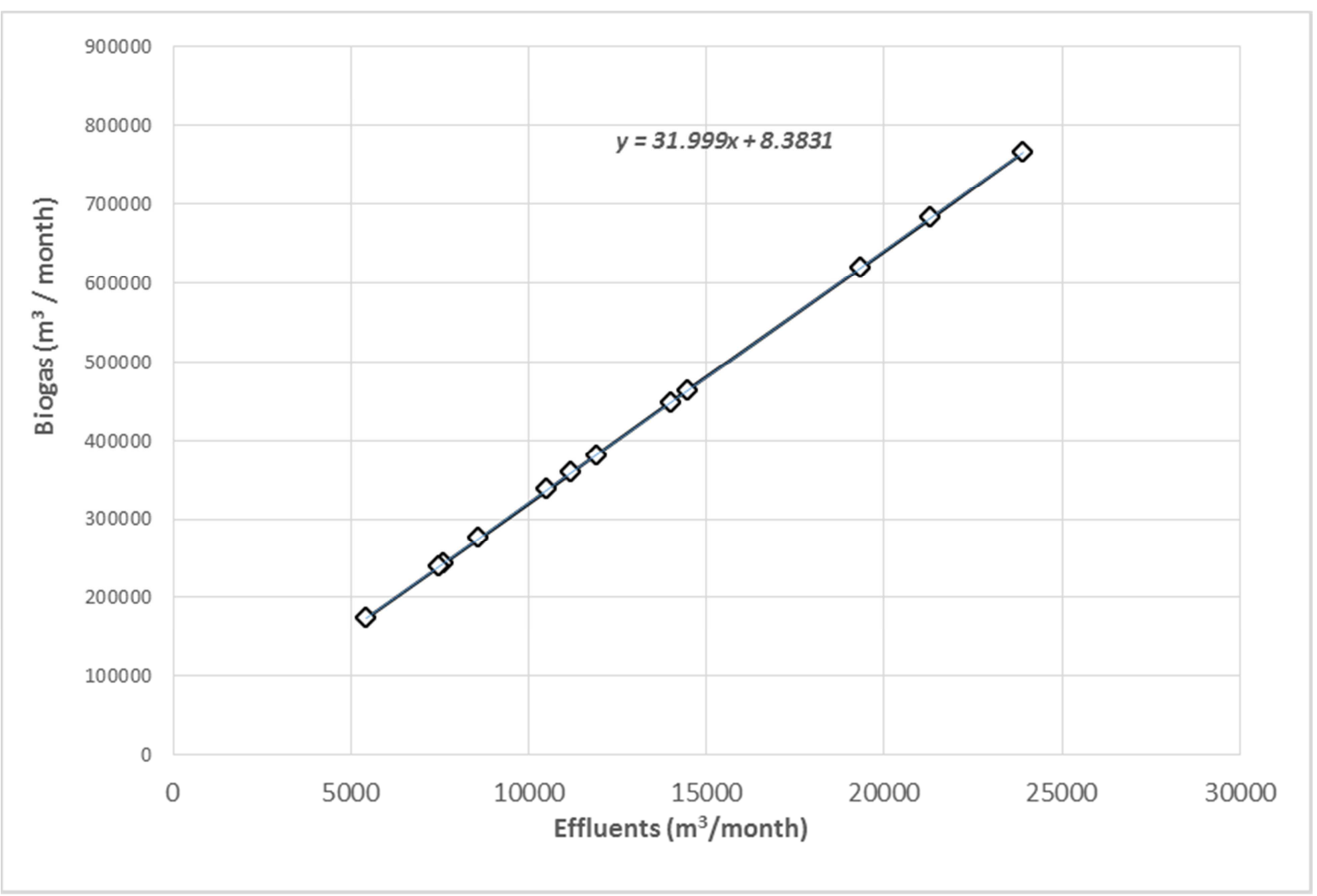

Figure 4. Production of biogas according to the flow of effluents.

For the rest of the work, it will be assumed that $1 \mathrm{~m}^{3}$ of effluent generates an average of $32 \mathrm{~m}^{3}$ of biogas. From the actual amount of palm oil fruits treated and the amount of effluents discharged per month, it can be deduce the amount of biogas generated monthly. (Figure 5) 


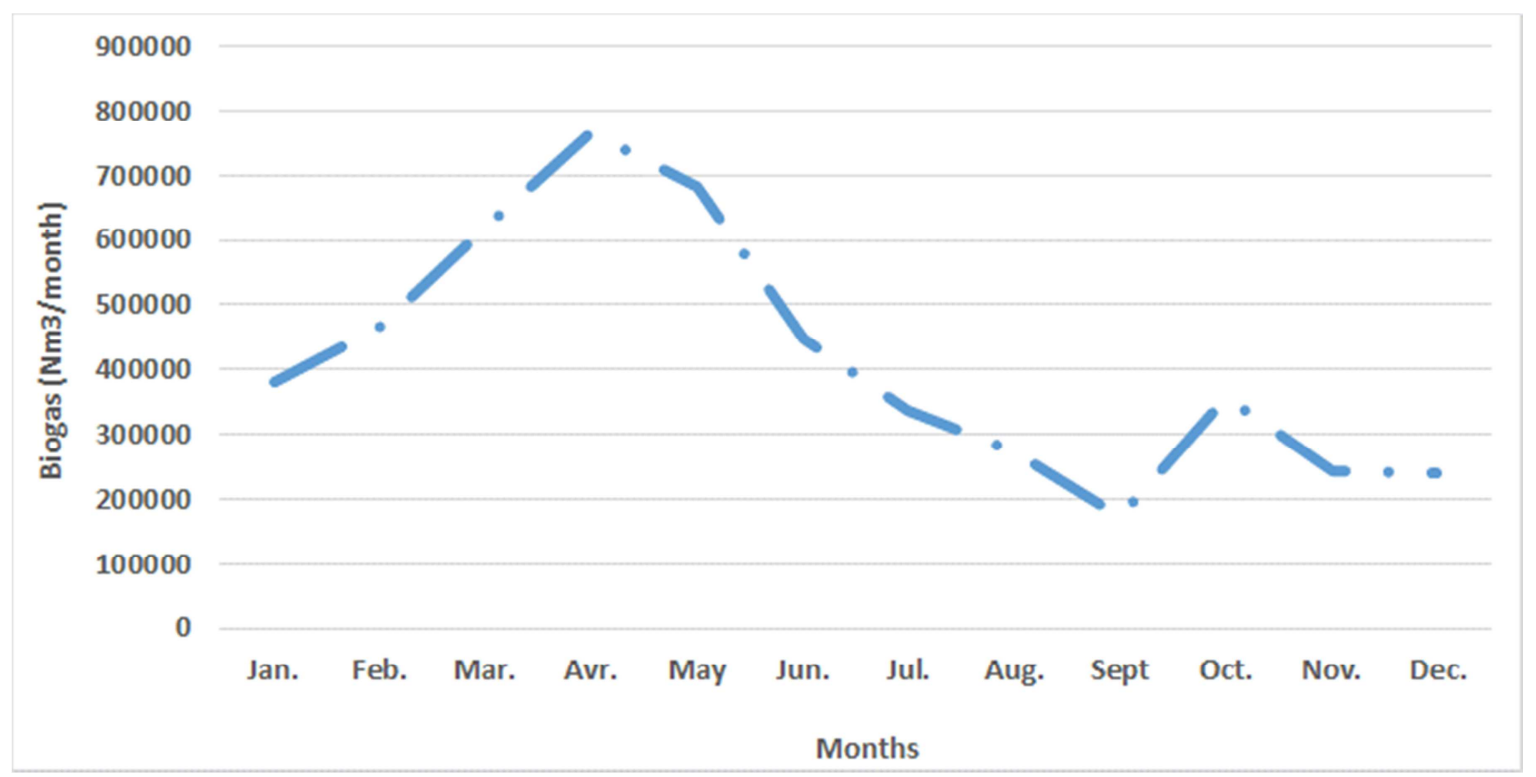

Figure 5. Monthly production of biogas by the palm oil process industry.

Figure 5 shows that the biogas production is subdivided into 3 parts according to the rate of production of palm oil fruits bunch:

1. High production period, from March to May: a biogas production of about $600,000 \mathrm{Nm}^{3} /$ month, due to the high rate of incoming palm oil fruits bunch;

2. Average production period, from January to February and in June: about $400000 \mathrm{Nm}^{3}$ / month of biogas due to average availability of palm oil fruits;

3. Period of low production, from July to December. The production of biogas varies from 200,000 to 300,000 $\mathrm{Nm}^{3} /$ month of biogas and corresponds to the period of low availability of the palm regimes.

The amount of biogas produced depends on the amount of palm oil fruits processed at the plant. Since the industrial palm oil plant processes an average of 250,000 tons of palm oil fruits per year, the estimated amount of biogas is $6,125,000 \mathrm{Nm}^{3} /$ year.

\subsection{Biogas Applications}

Biogas from anaerobic digestion containing $60 \% \mathrm{CH}_{4}$. This $\mathrm{CH}_{4}$ is convertible in all useful forms of energy [6].

1. In heat: The biogas can be directly used in a boiler, to produce thermal energy in the form of hot water, steam or hot air for the production of electricity.

2. In electricity: Biogas can supply a cogeneration unit (gas engine or turbine), which simultaneously produces two types of directly usable energies: electrical energy and thermal energy.

\subsubsection{Biogas for Heat as Thermal Energy}

Biogas containing $60 \% \mathrm{CH}_{4}$ can be used as a gaseous fuel to power a boiler in order to produce steam. This steam is used to power steam turbine that will generate electricity. It should be noted that, $1 \mathrm{Nm}^{3}$ of biogas at the atmospheric pressure and at $0^{\circ} \mathrm{C}$ with a Low Heat Value (LHV) of $21 \mathrm{MJ}$

\section{0}

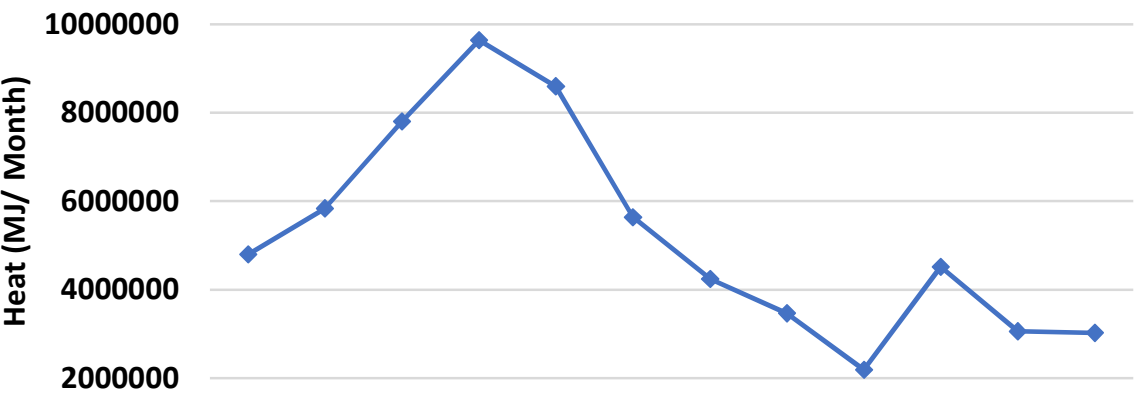

0

Jan. Feb. Mar. Avr. May Jun. Jul. Aug. Sept Oct. Nov. Dec. Months

Figure 6. Curve of monthly heat expected. 
The production of biogas is a function of the production of treated palm oil fruits. There will also be three major phases. The amount of heat energy is estimated at 100,800 GJ / year (see Figure 7).

\subsubsection{Biogas for Electricity Production}

The biogas coming out of the purification can be directly used in a biogas engine as a gaseous fuel to produce electricity. The following relations are used to determine producible energy and energy produced per hour.

$$
\begin{gathered}
\text { Producible Energy }=\frac{5000 * 4.185}{3600} \times 0.6 \times \text { quantity of biogas }(\mathrm{kW}) \\
\text { Energy produced per hour }=\text { Power }=\frac{\text { productible energy }}{\text { number of days } \times 24}(\mathrm{kWh})
\end{gathered}
$$

Figure 7 below summarizes the potential of producible energy, power energy and biogas produce per month during one year of production.

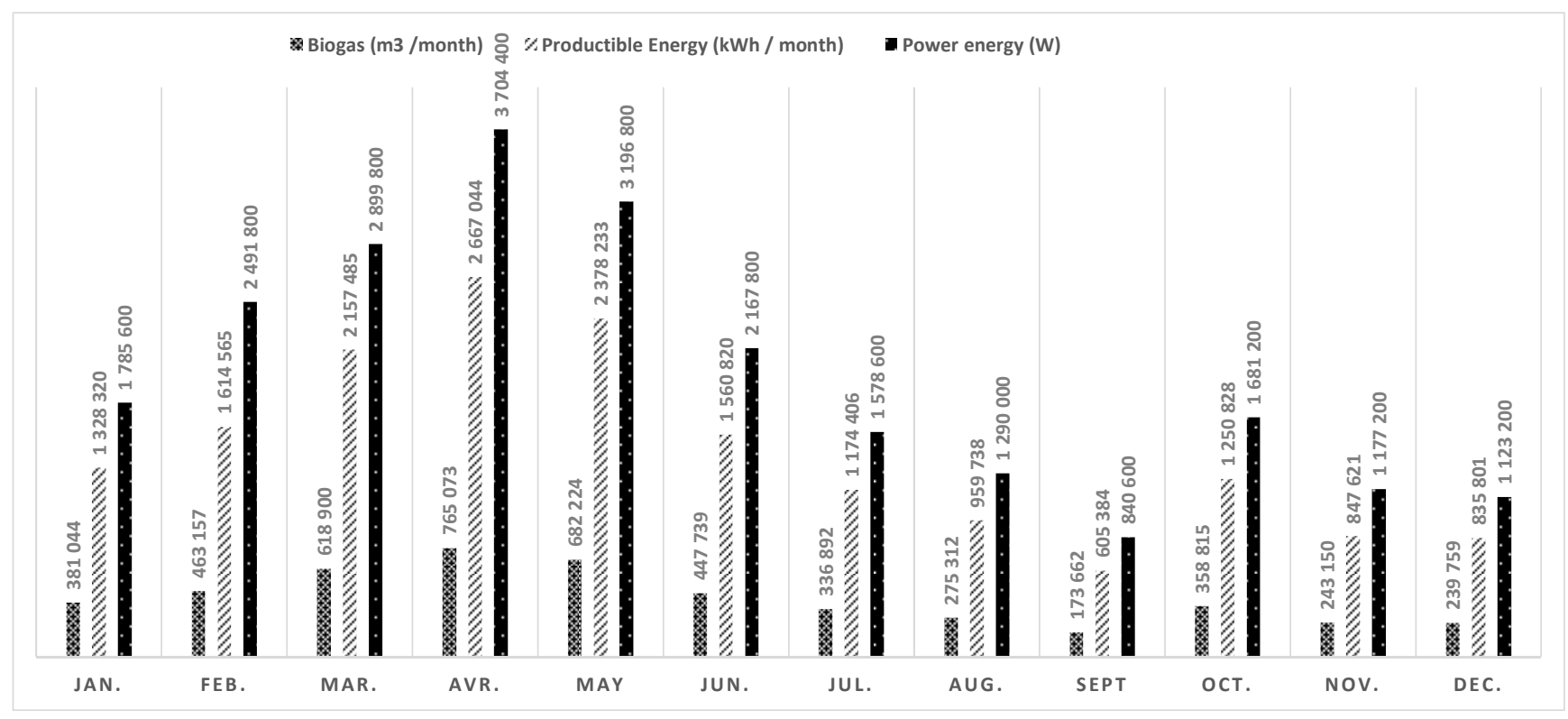

Figure 7. Producible energy, power energy and biogas per month.

\section{Conclusion}

This work on the pre-feasibility study for the production of electricity using liquid effluents from an agro-industrial palm oil fruits bunch company made it possible to evaluate the energy potential of liquid effluents through biogas generated: biogas production fluctuating between 32 at $39 \mathrm{~m}^{3}$ of biogas / $\mathrm{m}^{3}$ of mixture with a degradation of nearly $75 \%$ of the COD concentration under anaerobic conditions. Short stay of bacteria (5 days) during the production of biogas under anaerobic conditions. The upgrading process envisaged is the mechanization of future waste using bio-digesters. Recovered biogas can be used as fuel in internal or external combustion engines for the production of electrical energy.

\section{References}

[1] CIAPOL, MISE EN CONFORMITE DES HUILERIES DE PALMCI, Convention n $n^{0} 02 / 07 / 04 / 2015 /$ CIAPOL-PALMCI, Inspection et Evaluation de la qualité des rejets et émissions des eaux usées de process des huileries de PALMCI et leur impact dans le milieu récepteur.

[2] Ministère de l'Environnement, des Eaux et Forêts, (2008).
Arrêté $\mathrm{N}^{\circ} 01164 / \mathrm{MINEEF/CIAPOL/SDIIC} \mathrm{du} 04$ Nov. 2008, portant Réglementation des Rejets et Emissions des Installations Classées pour la Protection de l'Environnement. Ministère de l'Environnement, des Eaux et Forêts/Centre Ivoirien Antipollution.

[3] Ph. Dufour, (1982), Influence des conditions de milieu sur la biodégradation des matières organiques dans une lagune tropicale, Antenne ORSTOM, Institut National de la Recherche Agronomique (INRA), 74203 Thonon-les-Bains, France. OCEANOLOGICA ACTA 1982 - VOL. 5 - No 3, ISSN: 0399-1 784/.

[4] Effebi K. R. (2009) lagunage anaérobie: modélisation combinant la decantation primaire et la degradation anaérobie, Thèse de doctorat, Sciences et gestion de l'environnement, Université de Liège.

[5] Schanes, K., Dobernig, K., \& Gözet, B, (2018), Food waste matters-A systematic review of household food waste practices and their policy implications. Journal of Cleaner Production, 182, 978-991.

[6] Zamanzadeh, M., Hagen, L. H., Svensson, K., Linjordet, R., \& Horn, S. J. (2017). Biogas production from food waste via codigestion and digestion-effects on performance and microbial ecology. Scientific reports, 7(1), 17664. 
[7] R. Borja, C. J. Banks, (1994), kinetics of methane production from palm oil mill effluent in an immobilised cell bioreactor using saponite as support medium, Elsevier, p209- 214, ISSN 0960-8524.

[8] R. Bourgeois et D. Cogniel, «Mémotech électrotechnique plus», 7 édition page $95-192$; 449-452 et 592. ème.

[9] ADEME, (1999), le Biogaz et sa valorisation, Guide méthodologique, ADEME - GDF Paris.

[10] KOUADIO MARC CYRIL1, KOUAKOU ADJOUMANI RODRIGUE; KRA ESSI; TROKOUREY ALBERT 1, AKICHI AGBOUÉ, (2018), anaerobic bioconversion of food waste into energy: Case study of the food waste from Akouedo landfill, Côte d'Ivoire, JOURNAL OF ULTRA CHEMISTRY. JUC Vol. 14(4), 142-145 Periodicity 2Monthly. ISSN 0973-3450.
[11] P Arveen Fatemeh Rupani, Rajeev Pratap Singh, M. Hakimi Ibrahim and Norizan Esa, (2010), Review of Current Palm Oil Mill Effluent (POME) Treatment Methods: Vermicomposting as a Sustainable Practice, World Applied Sciences Journal 10(10): 1190-1201, ISSN 1818-4952.

[12] Chin, M. J., P. E. Poh, B. T. Tey, E. S. Chan and K. L. Chin, (2013), Biogas from palm oil mill effluent (POME): Opportunities and challenges from Malaysia's perspective. Renewable Sustainable Energy Rev, 26: 717-726.

[13] Metcalf, Eddy, (2003), Wastewater engineering treatment and reuse. New York, USA: McGraw-Hill; p. 96-7. ISBN-13: 9780071241403.

[14] Yacob, S., Hassan, M. A., Shirai, Y., Wakisaka, M., and Subash, M., (2006), "Baseline Study of Methane Emission from Anaerobic Ponds of Palm Oil Mill Effluent Treatment," Sci. Total Environ. 366, pp. 187-196. 